\title{
Effect of Trypsin on The Functional Properties of Salted and Ultrafiltrated Whey Protein Concentrates
}

\author{
Eman M. Ibrahim* and Mohamed Abed Ghanimah** \\ ${ }^{*}$ Department of Dairy Science, Faculty of Agriculture, Kafrelsheikh University, Egypt, \\ Prince Sattam Bin Abdulaziz University, Al Kharj, Saudi Arabia, \\ ** Department of Dairy Science, Faculty of Agriculture, Kafrelsheikh University, Egypt
}

\begin{abstract}
$\mathbf{T}$ HIS RESEARCH aimed to study the effect of hydrolysis of whey protein concentrates (WPCs) using trypsin enzyme on their functional properties and use of the modified concentrates in the manufacture of yogurt. Two types of whey were used, sweet whey from Ras cheese and salted whey from Domiati cheese manufacture. Whey protein concentrates were prepared by ultrafiltration of the sweet whey (UFWPC), and precipitation of the salted whey (SWPC) at $90^{\circ} \mathrm{C} / 20 \mathrm{~min}$ and $\mathrm{pH}$ 4.6. The prepared whey protein concentrates were treated with trypsin enzyme at concentrations of $0.15,0.3$ and $0.5 \mathrm{~g}$ enzyme per $100 \mathrm{~g}$ protein, and freeze dried. The results showed that the hydrolysis of whey protein concentrates had insignificant effect on the moisture, fat, ash and lactose, while the total nitrogen content and the degree of degradation significantly increased by increasing the concentration of the enzyme. Water and fat absorption capacities were increased by increasing the enzyme concentration and were higher in UFWPC. Emulsification capacity, foaming properties and the ability to form gel were improved by increasing the concentration of the enzyme. The replacement of skim milk powder with hydrolyzed WPCs (by $0.5 \mathrm{~g}$ trypsin $/ 100 \mathrm{~g}$ protein) in the manufacture of yogurt increased TS, TN and ash content and decreased the $\mathrm{pH}$. Curd syneresis significantly decreased in all treatments compared to control, however treatments with UFWPC exhibited the lowest values. The substitution of 50\% and $75 \%$ skim milk powder (SMP) with SWPC and UFWPC in order, had no effect on sensory properties of the yogurt compared to control.
\end{abstract}

Keywords: Trypsin, Whey protein concentrates, Solubility, Emulsification, Foaming, Yogurt, Syneresis

\section{Introduction}

Whey, the important by-product of the cheese industry, contains highly nutritional and biological proteins. Whey protein is an excellent source of essential amino acids needed by the human body, and branch chained amino acids (Jimenez et al., 2012 and Yadav et al., 2015). Whey protein products are considered as functional ingredients, and their functionality is related to the protein content and composition (Huck-Iriart et al.,2014 and Ghanimah, 2018).

Several factors could affect or alter the functional properties of whey proteins like the processing conditions. Sever heat treatment can impair the functional properties of whey proteins due to the denaturation and aggregation (Morr and Ha, 1993). The functionality of whey proteins can be improved by modification of protein via physical treatments and enzymatic modification (Kilara and Vaghela, 2018). It has been found that the functional properties can be improved by enzymatic hydrolysis of heat denatured whey protein (Kebary et al., 2009a). The modified whey proteins were more suitable for the use in the processed food industry, as well as they have health benefits, like antihypertensive, antibacterial, mineral-binding, antithrombotic and anti-gastric activities. (Gowda et al., 2006, Mota et al., 2006, Prieto et al., 2014 and Jeewanthi et al., 2015 a,b).

Several enzymes were used in the food industry to produce whey protein hydrolysates (WPHs) with various functional properties and biological activity. The most used enzymes to produce WPHs are digestive enzymes like trypsin, pepsin, and chymotrypsin. (Jeewanthi et al., 2015 a,b).

*Corresponding author : Email: e_ibrahim1972@yahoo.com 
Yogurt is an important dairy product in the world. The fortification of yogurt milk with skim milk powder improves the quality of the yogurt and prevents syneresis (Karam et al., 2013).

The present study was undertaken to study the effect of characterize hydrolysis of whey protein concentrates (WPCs) using trypsin and use of the modified concentrates in yogurt manufacture.

\section{Materials and Methods}

\section{Materials}

Trypsin 2000 used in the current study was obtained from Sigma Chemical Company St Louis, Mo, USA. Sweet whey from Ras Cheese manufacture was obtained from Mahmoud Mahdya Factory, Gharbia Governorate, Egypt. Whey was strained, separated using a cream separator to remove residual lipids, and then pasteurized. Whey was ultrafiltered using DDS Lap 20 UF equipment (APV/ Pasilac A / S, Silkeborg, Denmark; surface area $2 \mathrm{~m} 2$, GR 61 polysulphone membrane, Mo cut-off 20,000 ) at $40^{\circ} \mathrm{C}$ to a concentration of $28 \%$. This concentrate was designated as ultrafiltrated whey protein concentrate (UFWP). Salted whey of Domiati cheese manufactured from buffalo milk was obtained from a local factory. Whey protein concentrate (SWPC) was prepared by precipitation the salted whey at $90^{\circ} \mathrm{C} / 20 \mathrm{~min}$., and $\mathrm{pH} 4.6$.

\section{Condition of the enzymatic hydrolysis of whey protein concentrates}

The hydrolysis of whey protein concentrates with trypsin enzyme at concentrations of $0.15(\mathrm{~T} 1)$, 0.3 (T2) and 0.5(T3) g enzyme per $100 \mathrm{~g}$ protein was carried out as described by Kebary et al. (2009a). The $\mathrm{pH}$ was adjusted to 7.6 for the action of trypsin enzyme and incubated at $25^{\circ} \mathrm{C}$ for $2 \mathrm{~h}$, and to stop the enzyme action the temperature was raised to $75^{\circ} \mathrm{C}$ for $10 \mathrm{~min}$. The hydrolyzed whey protein concentrates were frozen overnight and freeze dried at $-60^{\circ} \mathrm{C}$ (Labconco Freeze Dryer 64312, Kansas, Missouri, USA.). The modified whey protein concentrates were analyzed for chemical composition and functional properties.

\section{Methods \\ Chemical analysis}

The degree of hydrolysis was determined as given by Yamashita et al. (1970). Moisture, fat, and ash contents were determined according to the methods given by AOAC (2000). The microKjeldhal method (Ling, 1963) was followed for determination of NPN and TN, whereas protein content was calculated from the following equation: Protein $=\mathrm{TN} \times 6.38$. Lactose content was determined according to the method of Barnett and Abd El-Tawab (1957).

\section{Functional properties:}

The solubility was determined according to Smith et al. (1959). Water absorption was measured according to the procedure of Sosulski (1962). Fat absorption was determined according to Sosulski et al. (1976). Emulsification capacity was determined according to Beuchat et al. (1975). The method of Lawhon et al. (1972) was used to determine foaming capacity $(\%)$ and foam stability. Gelation was measured according to the method described by Utsumi and Kinsella (1985).

\section{Preparation of yogurt}

Fresh cow milk (3\% fat and 8.5\% SNF) was supplemented with SMP (3\%) and served as a control. The skim milk powder was replaced with $50 \%, 75 \%$ and $100 \%$ hydrolyzed SWPC (YS1), (YS2) and (YS3), or hydrolyzed UFWPC (YUF1), (YUF2) and (YUF3). Yogurt was manufactured according to Tamime and Robinson (1999).

\section{Chemical analysis of yogurt}

Fresh and stored yogurt (for 12 days in a refrigerator) samples were analysed for total solids, ash and $\mathrm{pH}$ according to the methods given by AOAC (2000), TN was determined according to Ling (1963), and the protein content was calculated from the following equation: Protein $=\mathrm{TN} \times 6.38$. Curd syneresis was determined according to Mehanna and Mehanna (1989). Sensory evaluation was determined according to Narayana and Gupta (2013).

\section{Statistical analysis}

The ANOVA and Duncan's test (at $P<0.05$ ) were carried out and the average and standard error were calculated using the SPSS program (version 16), SPSS Inc., Chicago, IL, USA.

\section{Results and Discussions}

Table 1 shows that the addition of trypsin to the two types of whey protein concentrates gradually and significantly increased the degree of hydrolysis. However, the degree of hydrolysis was significantly higher in UFWPC than that in SWPC. Similar trends were observed by Jeewanthi et al. (2015b).

Table 2 shows the effect of the trypsin enzyme concentration on the chemical composition of whey protein concentrates. There were no significant changes in the moisture, lactose, fat, and ash, while there were significant differences in the total protein and NPN in both whey proteins concentrates. These results agree with Jeewanthi et al. (2015b). 


\section{Functional properties}

The solubility significantly increased by increasing the concentration of enzyme used. The modified and unmodified UFWPC exhibited much higher solubility indexes than those of SWPC (Table 3 ). Limited hydrolysis of protein leads to the reduction in the molecular weight and the increase in the solubility and the hydrophilicity resulting from the increase in amine groups and free carboxyl (Jeewanthi et al., 2015a). More extensive hydrolysis has been shown to increase the solubility (Flanagan and Fitzgerald, 2002). Jeewanthi et al. (2015 b) found that the solubility of WPHs was higher than that of untreated WPCs, and they attributed that to the increase in the number of ionizing groups (NH4+, COO-) and hydrophilicity with enzymatic hydrolysis.

It is clear from Table 3 that water and fat absorption capacities significantly increased by increasing the concentration of trypsin. Both modified and unmodified UFWPC exhibited higher water and fat absorption capacities than those of SWPC. Increased fat binding capacity was associated with an increase in hydrophobicity of the protein (Voutsinas \& Nakai, 1983 and Jeewanthi et al., 2015 a). Modification of SWPC and UFWPC with trypsin caused a significant increase in their emulsification capacities and this improvement increased by increasing the concentration of enzyme. The emulsification capacities of UFWPC were higher than those of SWPC (Table 3). Limited enzymatic hydrolysis has been found to successfully improve the interfacial properties of WPCs (Foegeding et al. 2002, Kilara \& Panyam, 2003 and Jeewanthi et al., 2015 a).

The results of foam capacity and foam stability are shown in Tables 3 and 4 , respectively. It is clear that foam capacity and foam stability increased by increasing the trypsin concentration in all treatments. Limited enzymatic hydrolysis promotes foaming aeration through more rapid absorption at the interface by reducing the peptide size (van der Ven et al., 2002). Proteins stabilize foam by strongly adsorbing to the air-water interfaces, forming viscoelastic adsorbed layers and leading to protein network with high viscosity (Rullier et al., 2010).

A gel is an intermediate structure between solid and liquid, which protein strands crosslink to form a network. Gelation is favored by large molecules of proteins, which form extensive networks by cross-linking in three dimensions and the ability of the denaturing (Jeewanthi et al., 2015 a). The ability of the protein to form gel increased by increasing the trypsin concentration in all treatments (Table 3).

In general, the hydrolysis of proteins by proteolytic enzymes leads to a reduction in the protein molecular weight, an increase in the ionizable groups, and the exposure of hydrophobic groups. These changes had a direct effect on the functional properties of the protein (Kilara and Vaghela, 2018).

TABLE 1. Effect of adding Trypsin to whey protein concentrates on the degree of hydrolysis (\%) (Data are means $\pm \mathrm{SE}$ )

Treatments (degree of hydrolysis\%)

Type of WPC Control

T1

0

0
T2

$4.8^{\mathrm{bB}}$

$7.6^{\mathrm{bA}}$
T3

$6.5^{\mathrm{aB}}$

$9.3^{\mathrm{aA}}$

T1, T2 and T3: whey protein concentrates hydrolyzed with trypsin at the rate of $0.15,0.3$ and $0.5 \%$ of protein respectively. SWPC: Salted Whey Protein Concentrate, UFWPC: Ultrafiltrated Whey Protein Concentrate.

Means in the same raw(treatments) with different lowercase superscripts are significantly different $(P<0.05)$. Means in the same column(type of WPC) with different uppercase superscripts are significantly different $(P<0.05)$. 
TABLE 2. Effect of adding Trypsin on the chemical composition of SWPC and UFWPC (Data are means \pm SE)

\begin{tabular}{ccccccccc}
\hline $\begin{array}{c}\text { Chemical } \\
\text { Composition }\end{array}$ & Control & T1 & T2 & T3 & Control & T1 & T2 & T3 \\
\hline \% Moisture & $6.04^{\mathrm{a}}$ & $6.07^{\mathrm{a}}$ & $6.11^{\mathrm{a}}$ & $6.15^{\mathrm{a}}$ & $7.10^{\mathrm{a}}$ & $7.10^{\mathrm{a}}$ & $7.16^{\mathrm{a}}$ & $7.19^{\mathrm{a}}$ \\
Lactose\% & $13.0^{\mathrm{a}}$ & $13.06^{\mathrm{a}}$ & $13.08^{\mathrm{a}}$ & $13.10^{\mathrm{a}}$ & $16.70^{\mathrm{a}}$ & $16.82^{\mathrm{a}}$ & $16.75^{\mathrm{a}}$ & $16.78^{\mathrm{a}}$ \\
Fat\% & $1.1^{\mathrm{a}}$ & $1.1^{\mathrm{a}}$ & $1.1^{\mathrm{a}}$ & $1.1^{\mathrm{a}}$ & $1.0^{\mathrm{a}}$ & $1.0^{\mathrm{a}}$ & $1.0^{\mathrm{a}}$ & $1.0^{\mathrm{a}}$ \\
Total Protein\% & $67.30^{\mathrm{d}}$ & $68.01^{\mathrm{c}}$ & $69.07^{\mathrm{b}}$ & $70.0^{\mathrm{a}}$ & $61.20^{\mathrm{d}}$ & $61.80^{\mathrm{c}}$ & $62.20^{\mathrm{b}}$ & $62.88^{\mathrm{a}}$ \\
Total ash\% & $9.00^{\mathrm{a}}$ & $9.05^{\mathrm{a}}$ & $9.07^{\mathrm{a}}$ & $9.22^{\mathrm{a}}$ & $10.60^{\mathrm{a}}$ & $10.63^{\mathrm{a}}$ & $10.65^{\mathrm{a}}$ & $10.72^{\mathrm{a}}$ \\
NPN\% & $0.73^{\mathrm{d}}$ & $1.36^{\mathrm{c}}$ & $1.89^{\mathrm{b}}$ & $2.20^{\mathrm{a}}$ & $0.90^{\mathrm{d}}$ & $1.77^{\mathrm{c}}$ & $2.28^{\mathrm{b}}$ & $2.83^{\mathrm{a}}$ \\
\hline See Legend to Table 1 for details & & & & & & &
\end{tabular}

See Legend to Table 1 for details

Means in the same row with different lowercase superscripts are significantly different $(\mathrm{P}<0.05)$.

TABLE 3. Effect of adding Trypsin on functional properties of SWPC and UFWPC (Data are means \pm SE)

Functional properties

\begin{tabular}{|c|c|c|c|c|c|c|c|c|}
\hline & Control & T1 & $\mathbf{T 2}$ & T3 & Control & T1 & $\mathbf{T} 2$ & T3 \\
\hline Protein solubility index & $17.55^{\mathrm{c}}$ & $32.50^{\mathrm{b}}$ & $45.10^{\mathrm{a}}$ & $46.22^{\mathrm{a}}$ & $23.0^{\mathrm{c}}$ & $23.00^{\mathrm{c}}$ & $90.85^{\mathrm{b}}$ & $92.14^{\mathrm{a}}$ \\
\hline Water absorption capacity $(\mathrm{g} / \mathrm{g})$ & $2.31^{\mathrm{d}}$ & $3.73^{\mathrm{c}}$ & $4.22^{\mathrm{b}}$ & $4.91^{\mathrm{a}}$ & $2.54^{\mathrm{d}}$ & $4.27^{\mathrm{c}}$ & $4.77^{\mathrm{b}}$ & $5.38^{\mathrm{a}}$ \\
\hline Fat absorption capacity $(\mathrm{g} / \mathrm{g})$ & $1.52^{\mathrm{c}}$ & $2.03^{\mathrm{b}}$ & $2.36^{\mathrm{a}}$ & $2.42^{\mathrm{a}}$ & $1.77^{\mathrm{d}}$ & $2.42^{\mathrm{c}}$ & $2.75^{\mathrm{b}}$ & $3.17^{\mathrm{a}}$ \\
\hline $\begin{array}{l}\text { Emulsification capacity ( } \mathrm{ml} \text { of } \\
\text { oil/g of sample) }\end{array}$ & $201.4^{\mathrm{d}}$ & $220.50^{c}$ & $235.20^{\mathrm{b}}$ & $245.3^{\mathrm{a}}$ & $211.3^{\mathrm{d}}$ & $231.52^{\mathrm{c}}$ & $260.91^{b}$ & $266.3^{\mathrm{a}}$ \\
\hline Foam capacity $(\%)$ & $9^{c}$ & $25^{\mathrm{b}}$ & $25^{\mathrm{b}}$ & $28^{\mathrm{a}}$ & $10^{\mathrm{d}}$ & $27^{\mathrm{c}}$ & $32^{\mathrm{b}}$ & $35^{\mathrm{a}}$ \\
\hline Gelation Capacity (\%) & $18.5^{\mathrm{a}}$ & $16.5^{\mathrm{b}}$ & $14.50^{\mathrm{c}}$ & $11.5^{\mathrm{d}}$ & $17.5^{\mathrm{a}}$ & $15.5^{\mathrm{b}}$ & $14.1^{\mathrm{c}}$ & $11.2^{\mathrm{d}}$ \\
\hline
\end{tabular}

See Legend to Table (1) for details

Means in the same row with different lowercase superscripts are significantly different $(P<0.05)$

TABLE 4. Effect of adding Trypsin on foam stability of SWPC and UFWPC (Data are means \pm SE)

\begin{tabular}{ccccccccc}
\hline \multirow{2}{*}{ Standing Time (min) } & & \multicolumn{3}{c}{ SWPC } & & \multicolumn{3}{c}{ UFWPC } \\
& Control & T1 & T2 & T3 & Control & T1 & T2 & T3 \\
\hline 0 & $18^{\mathrm{A}}$ & $38^{\mathrm{A}}$ & $50^{\mathrm{A}}$ & $55^{\mathrm{A}}$ & $36^{\mathrm{A}}$ & $48^{\mathrm{A}}$ & $57^{\mathrm{A}}$ & $66^{\mathrm{A}}$ \\
15 & $15^{\mathrm{B}}$ & $21^{\mathrm{B}}$ & $30^{\mathrm{B}}$ & $35^{\mathrm{B}}$ & $34^{\mathrm{B}}$ & $42^{\mathrm{B}}$ & $47^{\mathrm{B}}$ & $54^{\mathrm{B}}$ \\
30 & $13^{\mathrm{C}}$ & $18^{\mathrm{C}}$ & $21^{\mathrm{C}}$ & $25^{\mathrm{C}}$ & $32^{\mathrm{C}}$ & $37^{\mathrm{C}}$ & $40^{\mathrm{C}}$ & $42^{\mathrm{C}}$ \\
45 & $12^{\mathrm{C}}$ & $14^{\mathrm{D}}$ & $15^{\mathrm{D}}$ & $17^{\mathrm{D}}$ & $30^{\mathrm{D}}$ & $34^{\mathrm{D}}$ & $36^{\mathrm{D}}$ & $38^{\mathrm{D}}$ \\
60 & $11^{\mathrm{C}}$ & $13^{\mathrm{D}}$ & $14^{\mathrm{D}}$ & $15^{\mathrm{E}}$ & $25^{\mathrm{E}}$ & $32^{\mathrm{E}}$ & $34^{\mathrm{E}}$ & $35^{\mathrm{E}}$ \\
75 & $10^{\mathrm{D}}$ & $9^{\mathrm{E}}$ & $9^{\mathrm{E}}$ & $9^{\mathrm{F}}$ & $25^{\mathrm{E}}$ & $22^{\mathrm{F}}$ & $24^{\mathrm{F}}$ & $25^{\mathrm{F}}$ \\
90 & $10^{\mathrm{D}}$ & $6^{\mathrm{F}}$ & $7^{\mathrm{F}}$ & $8^{\mathrm{F}}$ & $25^{\mathrm{E}}$ & $21^{\mathrm{F}}$ & $24^{\mathrm{F}}$ & $24^{\mathrm{F}}$ \\
\hline
\end{tabular}

See Legend to Table (1) for details

Means in the same column with different uppercase superscripts are significantly different $(\mathrm{P}<0.05)$

J. Sus. Agric. Sci. 44, No. 3 (2018) 
Chemical composition and sensory properties of yogurt

It was noticed from Fig. 1 that replacement of SMP with the modified WPCs (using $0.5 \mathrm{~g}$ trypsin / $100 \mathrm{~g}$ protein) increased the TS, protein and ash content and decreased the $\mathrm{pH}$ value compared with control, while the type of WPC had insignificant effect. These results agree with Kebary et al. (2009 b) and Roumanas et al. (2016). Figure 2 shows that the replacement of SMP with modified WPCs significantly decreased $(\mathrm{P}<0.05)$ the curd syneresis compared with control, and the yogurt with UFWPC had the lowest values. These results may be due to the high protein content in treated yogurt samples. Curd syneresis decreased after 6 days and increased at the end of the storage (12 days). The sensory properties improved (Fig. 3 ), and the substitution of SMP with SWPC and UFWPC up to $50 \%$ and $75 \%$, in order, did not affect the sensory properties of the treated yogurt samples compared to the control.

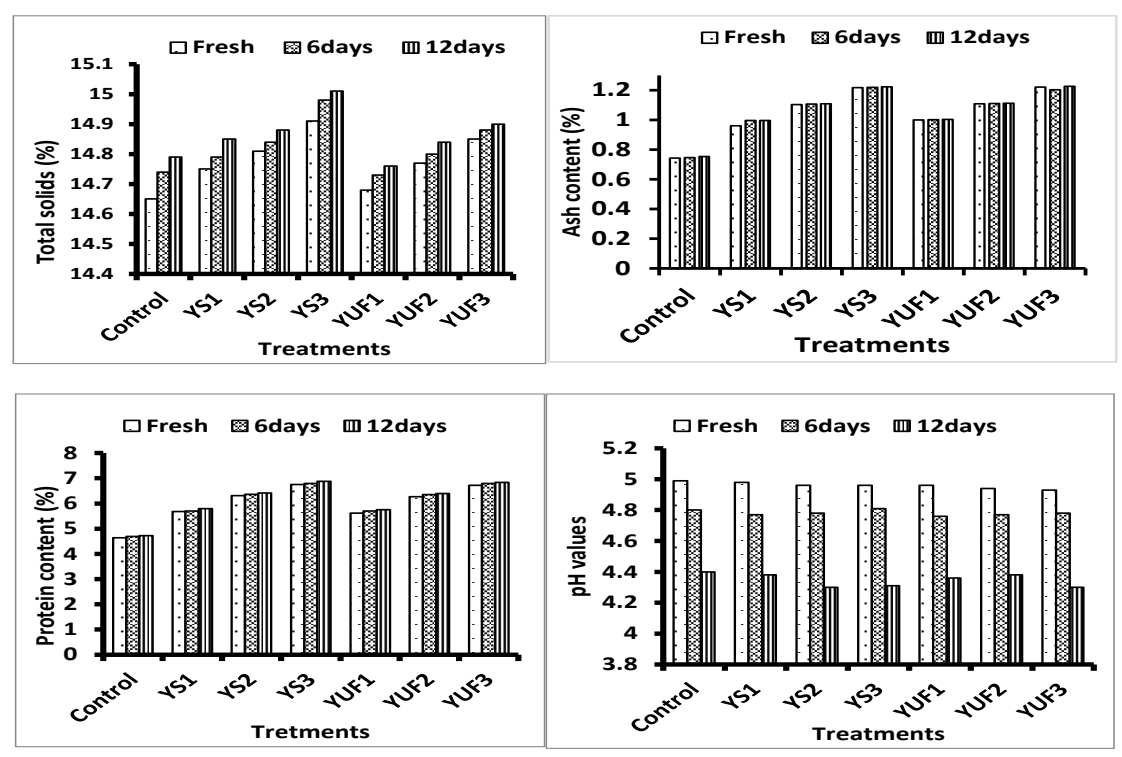

Fig 1. Effect of replacement of skim milk powder with modified whey protein concentrates on some chemical properties of yogurt

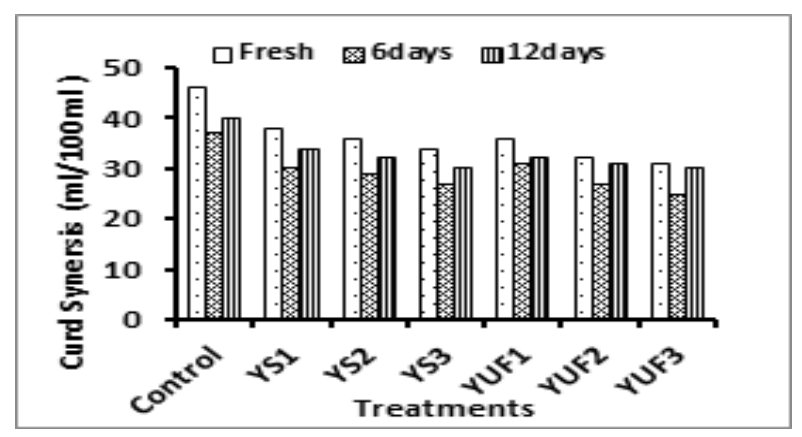

Fig 2. Effect of replacement of skim milk powder with modified whey protein concentrate on curd syneresis of yogurt 

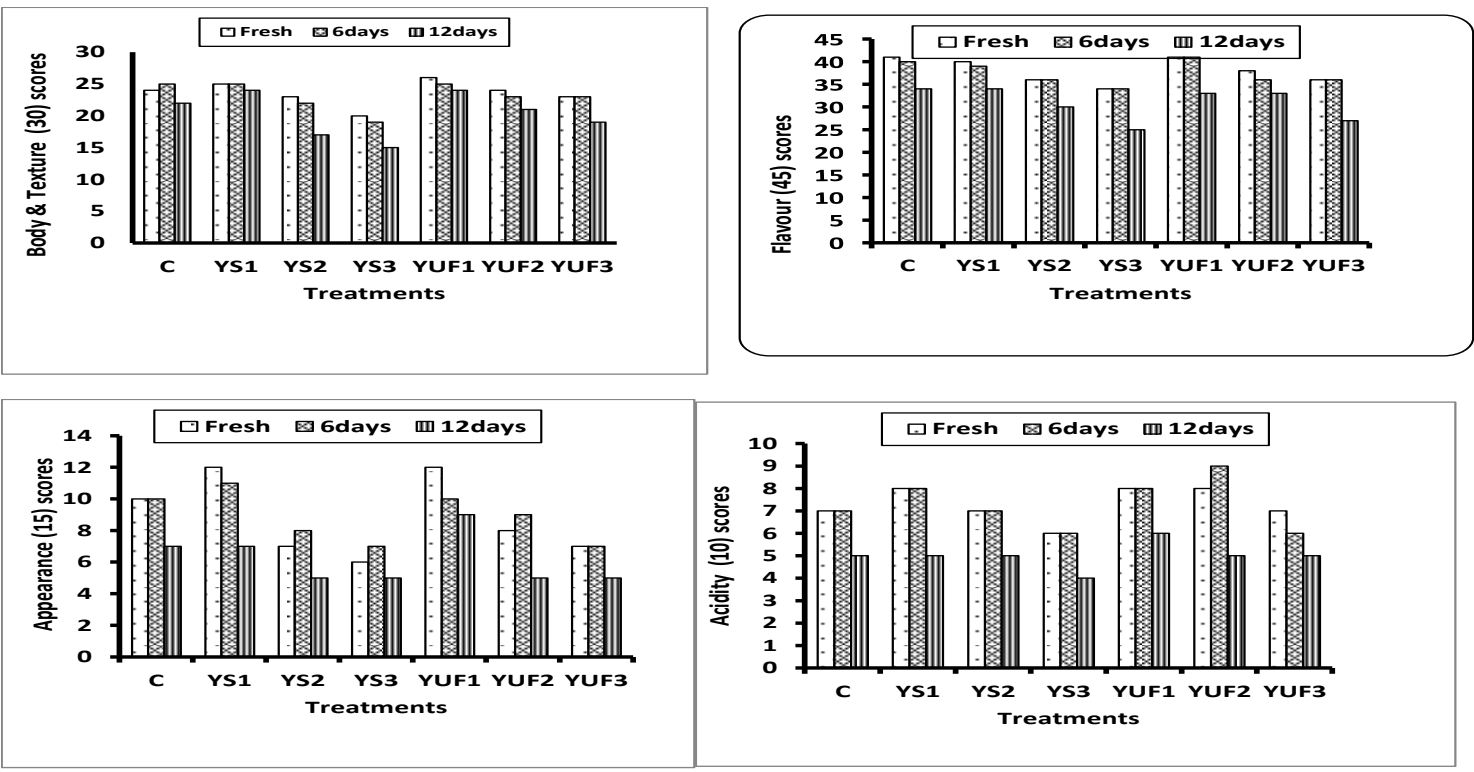

Fig 3. Evaluation of sensory properties of yogurt made with hydrolyzed whey protein concentrates during storage period

\section{Conclusions}

It could be concluded that the modification of the prepared WPCs using trypsin significantly improved their functional properties. The modified whey protein concentrates with $0.5 \mathrm{~g}$ trypsin $/ 100$ $\mathrm{g}$ protein can be used to replace skim milk powder to enhance the properties of Yogurt.

\section{References}

AOAC (2000) Official Methods of Analysis, 17 $7^{\text {th }}$ ed, Association Official Analytical Chemists, Washington DC.

Barnett, A.J.G. and Abd-El-Tawab, G. (1957) A rapid method for determination of lactose in milk and cheese. J. Food Sci. Agric. 8, 437-441.

Beuchat, L.R.; Cherry, J.P. and Quinin, M.R. (1975) Physicochemical properties of peanut flour as affected by proteolysis. J. Agric. Food Chem. 23,616-620.

Flanagan, J. and Fitzgerald, R.J. (2002) Physicochemical and nitrogen solubility properties of Bacillus proteinase hydrolysates of sodium caseinate incubated with transglutaminase pre and posthydrolysis. J. Agric. Food Chem. 50, 5429-5436.

Foegeding, E.A., Davis, J.P., Doucet, D. and Mc Guffey, M.K. (2002) Advances in modifying and understanding whey protein functionally. Trends Food Sci. Technol. 13,151-159.

Ghanimah, M.A. (2018) Functional and technological aspects of whey powder and whey protein products. Int. J. Dairy Technol. 71,454-459.
Gowda, L.R., Rao, A. and Prakash, V. (2006) Process for the preparation of angiotensin converting enzyme (ACE) inhibitors and its use. U.S Patent, 7,125, $702 \mathrm{~B} 2$.

Huck-Iriart, C., Rincón-Cardona, J.A. and Herrera, M.L. (2014) Stability of whey protein concentrate / sunflower oil emulsions as affected by sucrose and xanthan gum. Food Bioprocess Technol. doi: 10.1007/s11947-014-1290-1

Jeewanthi, R.K.C., Lee Na-Kyoung and Hyum- Donq Paik (2015a) Improved Functional characteristics of whey protein hydrolysates in food industry. Korean J. Food Sci. Anim. Resour. 35, 350-359.

Jeewanthi, R.K.C., Lee Na-Kyoung, Lee SiKyoung,Yoon, Y.C. and Hyum- Donq Paik (2015 b) Physicochemical characterization of hydrolysates of whey protein concentrates for their use in nutritional beverages. Food Sci. Biotechnol. 24,1335 - 1340.

Jimenez, X.T., Cuenca, A.A., Jurado, A.T., Corona, A.A. and Urista, C.R.M. (2012) Traditional methods for whey protein isolation and concentration: effects on nutritional properties and biological activity. $J$. Mex. Chem. Soc. 56, 369-377.

Karam, M.C., Gaiani, C., Hosri, C., Burgain; J. and Scher, J. (2013) Effect of dairy powders fortification on yogurt textural and sensorial properties: a review. J. Dairy Res. 80,400-409.

Kebary, K.M. K., Bardan, I.I., Moussa, A.M., Hussein, S.A. and Gaber, A.M. (2009a) Functional properties of enzyme modified whey proteins. Egyptian J. Dairy Sci. 37,215-226. 
Kebary, K.M.K., Hamed, A.I., Bradran, I.I., Hussein, S.A. and Gaber, A.M. (2009b) Manufactured of Yogurt from cow's milk fortified with trypsin modified whey proteins. Minufiya J. Agric. Res. 34,1525-1537.

Kilara, A. and Panyam, D. (2003) Peptides from milk proteins and their properties. Crit. Rev. Food Sci. Nutr. 43,607-633.

Kilara, A. and Vaghela, M. (2018) Whey proteins. pp 30-55, In: Yada, R. (Editor). Handbook of Food Proteins. Elsevier Ltd. https://doi.org/10.1016/ B978-1-84569-758-7.50003-4.

Lawhon, J.T., Cater, C.M. and Mattil, K.F. (1972) Comparative study of the whipping potential of an extract from several oilseed flours. Cereal Sci. Today. 17,241-245.

Ling, E.R. (1963) A Text Book of Dairy Chemistry. Vol. 2, Practical. 3rd ed., Chapman and Hall, London

Mehanna, N.M. and Mehanna, A.S. (1989) On the use of stabilizer for improving some properties of cow's milk yogurt. Egyptian J. Dairy Sci.17, 289-296.

Morr, C. and Ha, E. (1993) Whey protein concentrates and isolates: processing and functional properties. Crit. Rev. Food Sci. Nut. 33,431- 476.

Mota, M.V.T., Ferreira, I.M., Oliveira, M.B.P., Rocha, C., Teixeira, J.A., Torres D. and Goncalres, M.P. (2006) Trypsin hydrolysis of whey protein concentrates: characterization using multivariate data analysis. Food Chem. 94,278-286.

Narayana, N.M.N.K. and Gupta, V.K. (2013) Physical, textural and sensory attributes of plain set Yogurt made employing ultrafiltration technique as affected by titratable acidity during incubation. Proceedings of the Third International Symposium, SEUSL: 6-7 July, Oluvil, Sri Lanka

Prieto, C.A., Guadix, E.M. and Guadix, A. (2014) Recent patents on whey protein hydrolysates manufactured by proteolysis coupled to membrane ultrafiltration. Recent Pat. Chem. Emg. 3, 115-128.

Roumanas, R., Moatsou, G., Zoidou, E., Sakkas, L. and Moschopoulou, E. (2016) Effect of enrichment of bovine milk with whey proteins on biofunctional and rheological properties of low fat Yogurt type products. Curr. Res Nut.Food Sci. doi: http://dx.doi. org/10.12944/CRNFSJ.4.Special-Issue-October.14
Rullier, B., Axelos, M.A.V., Langevin, D. and Novales, B. (2010) $\beta$-lactoglobulin aggregates in foam films: Effect of the concentration and size of the protein aggregates. J. Colloid. Interface Sci. 343, 330-337.

Smith, C.R., Earle, F.R., Woleff, I.A. and Jones, Q. (1959) Seed protein solubility: Comparison of solubility characteristics of selected seeds protein. J. Agric. Food Chem. 7,133 - 136.

Sosulski, F.W. (1962) The centrifugal method for determining flour absorption in hard red spring wheats. Cereal Chem. 39, 344-350.

Sosulski, F.W.; Garrat, M.D. and Slinkard, A.E. (1976) Functional properties of ten legume flours. Can. Inst. Food Technol J. 9,66.

Tamime, A.Y and Robinson, R.K. (1999) Yogurt: Science and Technology. $2^{\text {nd }}$ ed., Woodhead Publishing Limited, England.

Utsumi, S. and Kinsella, J.E. (1985) Factors involved in soy protein gelation: effect of various reagents on gels made from $7 \mathrm{~S}, 11 \mathrm{~S}$ and soy isolate. J. Food Sci. 50,1278.

van der Ven, C., Gruppen, H., de Bont, D.B.A. and Voragen, A.G.J. (2002) Correlations between biochemical characteristics and foam-forming and stabilizing ability of whey and casein hydrolysates. J. Agric. Food Chem. 50, 2938-2946.

Voutsinas, L.P. and Nakai, S. (1983) A simple turbidimetric method for determining the fat binding capacity of proteins. J. Agric. Food Chem. 31, 58-63.

Yadav, J., Yan, S., Pilli, S.; Kumar, L., Tyagi, R. and Surampalli, R. (2015) Cheese whey: a potential resource to transform into bioprotein, functional/ nutritional proteins and bioactive peptides. Biotech. Advances. 33,756-774.

Yamashita, M., Arai, S., Matsuyama, J., Gonds, M., Kato, H. and Fujimaki, M. (1970) Enzymatic modification of protein in food stuffs: Part III. Phenomenal survey on a-chymotryptic Plastein synthesis from peptic hydrolysate of soy protein. Agr. Biol. Chem. 35, 86.

(Received: 3/9/2018; accepted: 1/10/2018) 


\title{
تأثير التربسين على الخواص الوظيفية لمركزات بروتين الثرش المملح و الثرش المركز بالترشيح الفيائق على
}

إيمان ابراهيم و محمد عابد غنيمه كلية الزراعة - جامعة كفر الثيخ ـ كفر عائه الثيخ - مصر

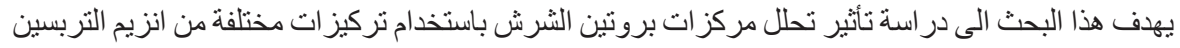

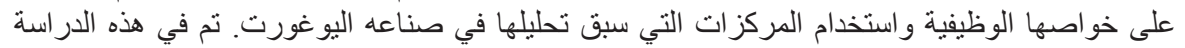

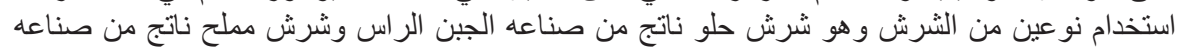

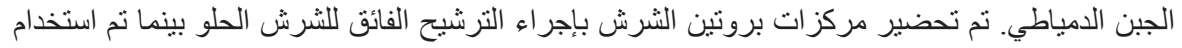

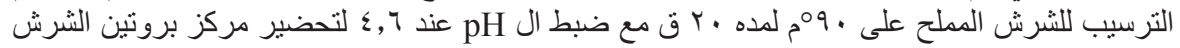

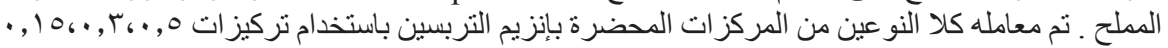

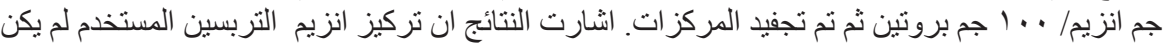

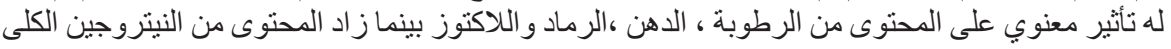

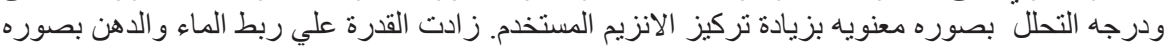

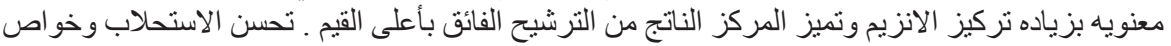

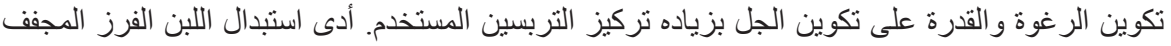

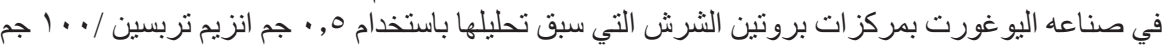

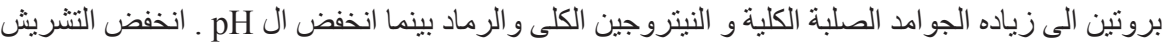

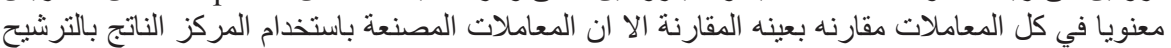

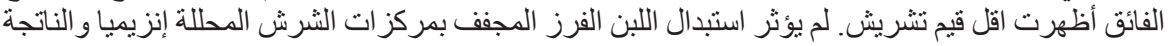

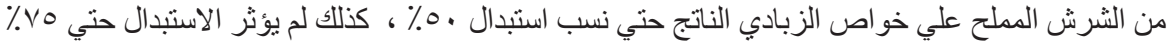

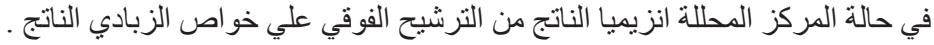

